OPEN ACCESS

Edited by: Lucillia Bezu,

Gustave Roussy Cancer Campus, France

Reviewed by:

Yuan Tang,

University of Toledo, United States Timothy Wigmore,

Royal Marsden Hospital, United Kingdom

*Correspondence: Maria F. Ramirez mframirez@mdanderson.org

Specialty section: This article was submitted to Surgical Oncology, a section of the journal Frontiers in Oncology

Received: 03 October 2021 Accepted: 18 November 2021 Published: 08 December 2021

Citation:

Ramirez MF and Cata JP (2021) Anesthesia Techniques and Long-

Term Oncological Outcomes.

Front. Oncol. 11:788918. doi: 10.3389/fonc.2021.788918

\section{Anesthesia Techniques and Long-Term Oncological Outcomes}

\author{
Maria F. Ramirez ${ }^{1,2 *}$ and Juan P. Cata ${ }^{1,2}$ \\ ${ }^{1}$ Department of Anesthesiology and Perioperative Medicine, The University of Texas MD Anderson Cancer Center, Houston, \\ TX, United States, ${ }^{2}$ Anesthesiology and Surgical Oncology Research Group, Houston, TX, United States
}

Despite advances in cancer treatments, surgery remains one of the most important therapies for solid tumors. Unfortunately, surgery promotes angiogenesis, shedding of cancer cells into the circulation and suppresses anti-tumor immunity. Together this increases the risk of tumor metastasis, accelerated growth of pre-existing micrometastasis and cancer recurrence. It was theorized that regional anesthesia could influence long-term outcomes after cancer surgery, however new clinical evidence demonstrates that the anesthesia technique has little influence in oncologic outcomes. Several randomized controlled trials are in progress and may provide a better understanding on how volatile and intravenous hypnotics impact cancer progression. The purpose of this review is to summarize the effect of the anesthesia techniques on the immune system and tumor microenvironment (TME) as well as to summarize the clinical evidence of anesthesia techniques on cancer outcomes.

Keywords: anesthesia, analgesia, cancer recurrence, metastasis, general anesthesia (GA), regional anesthesia palliative care - cancer pain, opioids, total intravenous anaesthesia (TIVA)

\section{INTRODUCTION}

Cancer is a major global health concern since it is the second cause of death after cardiovascular disease (1). According to the World Health Organization, an estimated 19.3 million new cancer cases were recorded in 2020 with almost 10 million cancer deaths worldwide (2). In addition, given the unprecedented effects of the COVID-19 pandemic on the health care system, many patients received a delayed diagnosis and treatment (including surgery) which will significantly impact their cancer prognosis. The American Cancer Society estimates an additional 25.7 million new cancer cases worldwide and 16.3 million cancer deaths by 2040 (3). This upward trend may be secondary to earlier cancer diagnosis and improvement in prevention and treatments.

Cancer treatment may involve a combination of chemotherapy, radiotherapy, immunotherapy and surgery. The latter is also used to provide diagnosis and palliative therapy for solid tumors. While surgical excision continues to be the gold standard treatment for cancer, accumulative evidence (mostly from preclinical studies) has suggested that surgery itself and multiple perioperative events (i.e., blood transfusion, analgesics and anesthetics) might accelerate the progression of minimal residual disease, formation of new metastatic foci and cancer recurrence (4). In this review, we will focus on key mechanisms that allow surgery to provide suitable conditions for shedding, implantation and subsequently proliferation or circulating tumor cells (CTCs). Additionally, we will provide a comprehensive review of the pre-clinical data on the effect of anesthesia technique (total intravenous anesthesia [TIVA] versus volatile anesthesia) and 
analgesia (regional versus opioid based techniques) on cancer cells, the TME and immunosurveillance. Lastly, we will summarize the clinical data regarding the effects of the anesthesia techniques on cancer outcomes including survival.

\section{THE ROLE OF SURGERY IN CANCER PROGRESSION}

\section{Surgery Triggers Inflammation Followed by Immunosuppression}

Cancer metastasis is the major cause of morbidity and mortality, and in fact it accounts for $90 \%$ of deaths in cancer patients (5). In order to successfully colonize a distant site CTCs must complete a sequence of events before they become clinically detectable metastasis. The development of metastasis therefore requires; 1) escape of tumor cells from primary tumor, 2) intravasation, 3) circulation in the blood stream, 4) extravasation through endothelial cells into the surrounding tissue, and 5) survival and proliferation in the TME by induction of angiogenesis and immune escape (Figure 1) (6). Also, an essential step on the metastatic process is the epithelial-mesenchymal transition (EMT). EMT allows the transformation of epithelial cancer cells into mesenchymal cancer cells (7). This phenotypic transformation enables mesenchymal cells to migrate, invade and resist apoptosis as they colonize distant sites. Cumulative evidence indicates that surgery increases the shedding of tumor cells into the circulation (8) and activates the sympathetic nervous response which ultimately triggers inflammation followed by immunosuppression (Figure 2) (9).

The initial acute inflammatory stress response is mediated by neutrophils, macrophages and monocytes at the site of injury. These immune cells release a massive production of proinflammatory cytokine including interleukin $-1 \beta$ (IL-1 $\beta$ ), interleukin-6 (IL-6), tumor necrosis factor $\alpha$ (TNF- $\alpha$ ) and neutrophils extracellular traps (NETs). All these cytokines shift CD4+ helper cells to a th1 profile (10). The Th1 profile, generally accepted as anti-tumoral, is characterized by the secretion of interferon gamma (INF)- $\gamma$ and IL-2 with regulation of the cell mediated immunity (11). It is important to point out that the inflammatory response is directly proportional to the degree of surgical trauma. Human studies assessing the effect of minimally invasive versus open surgery have shown significant differences between the two interventions when reporting the function of immune cells and cytokine profile(12); "Inflammatory Response After Laparoscopic Versus Open Resection of Colorectal Liver Metastases Data From the Oslo-CoMet Trial: Erratum," (13). For instance, laparotomy triggers higher concentrations of IL-6 than laparoscopic cancer surgery("Inflammatory Response After Laparoscopic Versus Open Resection of Colorectal Liver Metastases Data From the Oslo-CoMet Trial: Erratum," (13).

The surgical inflammatory response is followed by a compensatory anti-inflammatory response; however it can also lead to dysregulation of the cell mediated immunity with subsequent immunosuppression (14). IL-6 induces the release of prostaglandin $\mathrm{E}_{2}\left(\mathrm{PGE}_{2}\right)$ from macrophages (15). PGE2 is a lipid mediator that exerts its activity via $\mathrm{PGE}_{2}$ receptors (EP1-4). EP2 and EP4 are both $\mathrm{G}_{\mathrm{s}-\mathrm{couple}}$ receptors that signal through the adenylate cyclase-dependent cAMP/PKA/CREB pathways (16). The effects of $\mathrm{PGE}_{2}$ includes the inhibition of neutrophil, natural killer (NK) and T-cell mitogenesis (17). Furthermore, protanglandin regulates lymphatic vessles dilatation and therefore could enables cancer mestatasis (18). Additionally, $\mathrm{PGE}_{2}$ inhibits the production of IL-1 $\beta$, IL- 6 and TNF- $\alpha$ and stimulates the release of IL-10, IL-1Ra (19). This cytokine imbalance results in a shift toward th2 profile (pro-tumoral), which favors tumor growth by inhibiting cell-mediated immunity (20).

The stress response to surgery is also characterized by the secretion of cortisol and catecholamines (21). Cortisol can diffuse the cellular membrane to bind the glucocorticoid receptor intracellularly. This complex, then translocates into the nucleus where it interacts with glucocorticoid-responsive elements (DNA sequence) and different transcription factors such as NF-kB to inhibit or promote the production of inflammatory cytokines

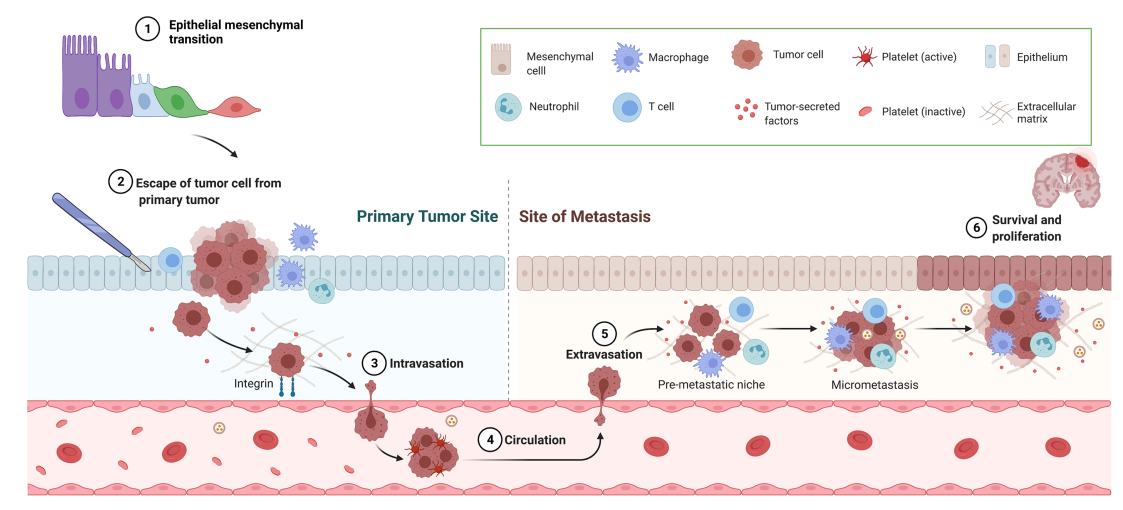

FIGURE 1 | Overview of metastatic cascade. This figure represents the necessary steps for successful metastasis including epithelial-mesenchymal transition, escape of tumor cell from primary tumor, intravasation, circulation, extravasation and survival and proliferation. 


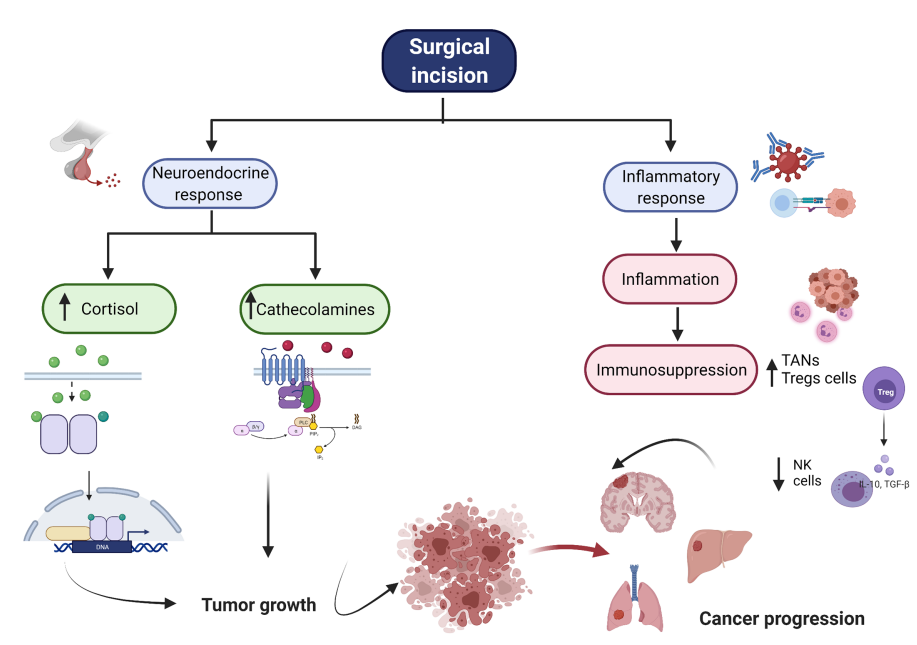

FIGURE 2 | Overview of Surgical Stress Response. The figure represents the neuroendorine and the inflammatory response associated with surgery. After surgical incision, there is an increase of cortisol and cathecholamines. Additionally, there is a profound inflammatory response followed by immunosupression. All these together enables cancer cells to growth, proliferate and produce distant metastasis. NK, natural killer cell, TAN, tumor associated neutrophiles, Tregs, regulartoy T cells.

(22). For instance, cortisol has shown a dual role in oral squamous cell carcinoma. At physiological stress levels (i.e., 10 nM) cortisol promoted the expression of IL-6 while higher pharmacological concentration (i.e., $1000 \mathrm{nM}$ ) produced the opposite findings (23). The sympathetic nervous system directly modulates cancer cells via $\beta$-adrenoreceptors-mediated activation of protein kinase A (PKA) (24). $\beta$-adrenoreceptors have been found in breast, prostate, lung, esophageal and liver cancer cells among others (25-29). The activation of $\beta$ adrenergic signaling by epinephrine or norepinephrine triggers an increase on cyclic adenosine monophosphate (cAMP) which directly modulate cancer cell growth, proliferation, invasiveness, angiogenesis and metastasis (24). One characteristic of cancer cells is the formation of invadopodia (actin-rick protrusions) which are formed to degrade and facilitate migration through the extracellular matrix (30). $\beta$-adrenoreceptors activation can promote an increase of invadopodia which correlates with increased tumor invasion in in vivo breast cancer models. Importantly, such effect is reversed by $\beta$-blockers (31).

\section{Surgery Induces Angiogenesis}

A critical step in the metastatic process is the development of new blood vessels (angiogenesis). The vascular endothelial growth factor (VEGF), an extensively studied molecules in angiogenesis, is considered a maker of poor prognosis for some cancers $(32,33)$. VEGF as well as its receptors (VGFR1 and VGFR2) have been found in cancer cells (34). The activation of VEFGR initiates MAPK signaling pathway with phosphorylation of ERK and ultimately promotion of cell proliferation (35). VEGF has been reported to be higher in cancer patients compared to control groups even before surgery (36-39). It has been theorized that high perioperative levels of VEGF might explain why cancer surgery might facilitate the growth of residual metastases disease early after surgery.

\section{Key Effectors Cells of the Immune Response in Cancer Surgery}

Neutrophils are the first line to respond to surgical trauma and defend against invading microorganisms. However, neutrophils have been shown to play a dual role since besides protecting from infection, neutrophils can also lead to cancer progression and tumor dissemination (40). Tumor associated neutrophils (TANs) are associated with poor overall survival in many types of cancers (41-43). Neutrophils can serve as chemotactic factor to attract cancer cells by releasing neutrophil extracellular trap (NETs)(L. 44). Surgery triggers the formation of NETs which can promote formation of metastasis. The inhibition of NETs after surgery powerfully counteract their pro-metastatic effects (45).

Natural killer cells are one of the main effector cells against cancer (46). Upon target cell recognition, NK cells mediate target cell lysis by two different mechanisms. First, the release of cytotoxic granules containing granzyme and perforins, and the induction of Fas ligand and TNF-related apoptosis ligand (TRAIL) (47). Second, activated NK cell secrete several cytokines such as INF- $\gamma$, TNF- $\alpha$ and chemokines (i.e., CCL3, CCL 4 and CCL5). Accumulated evidence suggests that NK cell cytotoxicity is decreased immediately after surgery secondary to surgical stress. This effect can last for several weeks (48). Additionally, the surgical stress impair the NK cells' capacity to secrete INF- $\gamma$ and therefore decreases the activation of the cellular immunity and subsequently antitumor immune response (49). The extent of the surgical insult impacts the function of these cells. For instance, laparoscopically assisted surgery resulted in better preservation of NK cell function compared to open procedures in patients with colon cancer (50).

Lymphocytes are an essential component for maintaining tolerance and preventing excessive inflammation. Postoperative lymphopenia or a high neutrophil-to-lymphocyte ratio (NLR) are independent biomarkers of cancer recurrence (51-53). NLR 
appears to be an appealing biomarker in cancer prognosis since its widely available, easily measured and inexpensive. A recent meta-analysis by Cupp et al. suggested an association between high NLR and poor cancer outcomes (54). For instance, Forget et al. demonstrated that preoperative high NLR in patients with breast, lung and renal cancer undergoing tumor resection was associated with higher risk or relapse and/or higher mortality (55). Similar findings in term of RFS and OS were found by Choi et al. in a cohort of non-small cell lung cancer (NSCLC) patients, however the correlation was only observed in patient with Stage I NSCLC (56). Among lymphocytes, regulatory T cells (Tregs) are also regulators of the anti-tumor immunity (57). Ghiringhelli et al. reported a high Tregs cell levels that correlated with a low number of NK cells that were also dysfunctional in gastrointestinal stromal tumor-bearing patients (58). Peripheral and tumor infiltrating Tregs levels are higher in patients with breast and pancreas cancer compared to healthy subjects. High levels of circulating tumor infiltrating Tregs have been associated with accelerated progression and poor prognosis of those cancers (59). While in the context of low levels of Tregs can predict the presence of postoperative complications, the impact of different peripheral concentrations of these cells after oncological procedures is less understood (60).

In summary, the perioperative period is critical for several steps leading to cancer metastasis. It has been indicated that anesthetics could also influence mechanisms such as NETs formation, EMT and angiogenesis. In the following section, we will summarize the preclinical and clinical evidence regarding the effects of the different types of anesthesia techniques on longterm cancer outcomes.

\section{INHALATIONAL AGENTS AND INTRAVENOUS ANESTHETICS FOR CANCER SURGERY}

\section{Preclinical Evidence Volatile Anesthetics}

Volatile anesthetics are commonly used during oncological surgery. There has been increasing interest in investigating the role of volatile anesthetics on cancer recurrence and metastasis. Preclinical data suggest that volatile agents promote the progression of cancer by direct and indirect mechanisms. Firstly, volatile anesthetic can directly modify (by either promoting or inhibiting) intracellular signals involved in key aspect of the cancer cell behavior such as proliferation, migration, invasion and sensitivity to chemotherapeutic agents. For instance, isoflurane (1.2\%) increased the proliferation and migration while decreasing apoptosis in glioblastoma stem cells by regulating the expression of hypoxia-inducible factor (HIF) $(61,62)$. In non-small cell lung cancer, isoflurane at $1 \%, 2 \%$ and $3 \%$ promoted proliferation, invasion and invasiveness via AktmTOR signaling (63). In a colorectal cancer cell line, desflurane (10.3\%) induces EMT and metastasis through dysregulation of miR-34/LOXL3 axis a well-known tumor suppressor (64).
Sevoflurane (2\% for six hours), in vitro, increases survival of breast cancer cells via modulation of intracellular $\mathrm{Ca}^{2+}$ homeostasis (65). Secondly, volatile anesthetics could facilitate cancer progression by inducing immunosuppression. For example, sevoflurane and desflurane attenuated NK cell cytotoxicity in vitro by inhibiting the expression of the adhesion molecule leucocyte- function $\mathrm{n}$ associated antigen (LFA-1) (66). In addition, isoflurane reduced the ability of NK cells to respond to INF- $\gamma$ stimulation. A phenomenon that lasted for 11 days (67). Importantly, sevoflurane, isoflurane and enflurane at 1.5 and 2.5 MAC reduced the release of TNF- $\alpha$ and IL-1 $\beta$ in human peripheral blood mononuclear cells (68).

Contrary to this previously cited evidence, a number of preclinical studies indicate that volatile anesthetics might have an anti-tumoral effect. For instance, concentration of sevoflurane from $1.7 \%$ to $5.1 \%$ significantly inhibits invasion and migration of lung carcinoma cells by decreasing the phosphorylation of $\mathrm{p}$ 38 MAPK, reducing HIF- $1 \alpha$ activation and downregulating matrix metallopeptidases (MMP) 2 and MMP-9 (69-71). In colon cancer, sevoflurane induced p53-dependent apoptosis while suppressing cell migration and invasion by regulating the ERK/MM-9 pathway (via miR-203) (72, 73). Lastly, sevoflurane at clinical $(2.5 \%)$ and toxic concentrations (5\% and $10 \%)$ inhibited viability, migration and invasion of osteosarcoma cells by inactivating PI3K/ATK pathway (74).

In summary, volatile anesthetics regulate important functions in cancer cells. Their inconsistent (pro and anti-tumoral) effects cancer cells and those of the TME could be explained by differences in experimental conditions such as, type of cell line, incubation time (ranged between 30 mins and 6 hours), type and concentration of volatile anesthetics (ranged between $0.5 \%$ $10 \%)$. For instance, some studies treated cancer cells with very high concentrations that are not usually employed in clinical practice and perhaps the "anti-tumoral" effect is most likely related to toxic concentrations of volatile anesthetics.

\section{Propofol}

Propofol based total intravenous anesthesia has gained attention in recent years. Most preclinical studies suggest that propofol inhibits tumor cell viability, proliferation, migration and invasion by regulating different signaling pathways. It inhibits proliferation, migration and invasion in colon cancer cells by upregulating miR-124-3p and downregulating AKT3 (75). Also in colon cancer, propofol decreases cell invasion via ERK1/2depenedent downregulation of MMP-2 and -9 (76). In lung cancer cells, propofol promotes apoptosis also via ERK1/2 via activation and upregulation of p53 (77), and decreases metastatic cell behaviors by inhibiting HIF-1 $\alpha$ (78) and MMPs-2,-7 and -9 (79). Similarly, it inhibits migration of breast cancer cells by inhibiting MMP expression via NF- $\kappa$ B pathway (80). In glioma cells, propofol reduced migration and invasion by blocking PI3K/AKT pathways via mi-R-206/ROCK1 axis (81). Moreover, propofol reduced oxidative stress and growth in glioma cells by suppressing the $\mathrm{Ca}^{2+}$-permeable $\alpha$-amino-3hydroxyl-5methylisoxazole-4-propionic acid (AMPA)receptor and divalent transporter 1(DMT1) (82). 
The anti-tumoral effect of propofol in cancer progression also entails indirect mechanisms such as the potentiation of NK cell cytotoxicity and reduction of inflammatory response. For instance, in colon cancer cells, propofol increased expression of activated receptor p30 and p44 in NK cells, which promoted NK cell activation and proliferation (83). Additionally, in esophageal squamous cell carcinoma cells, propofol enhanced the expression of cytotoxic effector molecules like granzyme B and IFN- $\gamma$ suggesting that NK cytotoxicity was increased (84). In terms of cytokine profile, propofol decreases pro-inflammatory cytokines such as IL-1 $\beta$, IL-6 and TNF- $\alpha$ (85) and inhibits PGE2 and COX activity (86). Moreover, propofol decreased NETs formation (through inhibition of p-ERK) without affecting neutrophil killing capacity $(87,88)$.

Altogether, propofol preferentially promotes anti-metastatic mechanism in cancer cells and those of the TME.

\section{Intravenous Ketamine, Dexmedetomidine and Lidocaine}

Ketamine is routinely used during cancer surgery to provide analgesia and reduce the use of volatile anesthetics and opioids. Increasing number of studies suggest that ketamine can modify proliferation and survival of cancer cells (89). For example, ketamine decreased intracellular $\mathrm{Ca}^{2+}$, expression of HIF-1 $\alpha$, p-AKT, p-ERK with subsequent reduction of VEGF expression and cell migration in colorectal cancer cells. Notably, all these changes were associated with NMDA receptor inhibition since $\mathrm{D}$-serine (NMDA activator) reversed the anti-tumoral effect of ketamine (90). Additionally, ketamine promotes apoptosis and inhibits cell growth proliferation in lung adenocarcinoma; throughout CD69 expression (91), hepatic cell carcinoma; throughout Bax-mitochondria-caspase protease pathway (92); pancreatic carcinoma via NMDA receptor type R2a (93) and ovarian cancer through the inhibition of long-non-coding RNAs PVT1 expression (89).

Dexmedetomidine has also gained interest due to its sedative and analgesic effects. In esophageal carcinoma, dexmedetomidine inhibits tumor growth and metastasis via upregulation of miR143-3p and reduction of levels of epidermal growth factor receptor 8 (94). Additionally dexmedetomidine enhances immune surveillance by inhibiting the p38 MAPK/NF- $\kappa \mathrm{B}$ signaling pathway; however, some authors have indicated that dexmedetomidine can stimulate proliferation of cancer cells (95, 96). For instance, dexmedetomidine induced secretion of IL-6 and promoted progression via STAT 3 activation in hepatocellular carcinoma (97). Similarly, it promoted tumor proliferation and migration via adrenergic signaling and upregulation of Bcl-2 and $\mathrm{Bcl}-\mathrm{xL}$ (anti-apoptotic proteins) in neuroglioma and lung carcinomas (98). In a rodent model of breast, lung and cancer colon, dexmedetomidine promoted tumor growth and metastasis (99).

Lidocaine is an amide local anesthetic that has gained popularity because of its anti-ileus effects and suggested beneficial properties in recovery after surgery. Lidocaine suppress tumor cells directly by modifying cancer cells signaling. For instance, lidocaine inhibited metastasis and proliferation of lung cancer cells by up-regulating miR-539 with subsequent blocking of EGFR signaling (100). Furthermore, lidocaine suppressed hepatocellular cell growth and induced apoptosis (via activation of caspase- 3 and regulation of $\mathrm{Bax} / \mathrm{Bcl}-2$ proteins through the MAPK pathway)( 101). Likewise, lidocaine inhibited cervical cancer cell growth and induced apoptosis by modulating lrnRNA-MEG3/miR-421/ BTG1 pathway (102).

Lidocaine has shown potent anti-inflammatory properties by decreasing both; pro-inflammatory cytokines (IL-1 $\beta$, IL-6 and TNF- $\alpha$ ) and intercellular adhesion molecules (I-CAM) expression $(103,104)$. Human studies have also confirmed this finding in a randomized controlled trial (RCT) where intravenous lidocaine was associated with significantly less production of IL-1ra, IL-6 with preservation of the lymphocyte proliferation (105). Lidocaine has also stimulated the function of NK cells of patients undergoing cancer surgery (106). Recently, a RCT looking at the effect of intravenous lidocaine infusion in breast cancer patients demonstrated a decrease in postoperative expression of NETosis (which is associated with disease progression) and MMP3 (107). Lastly, lidocaine has shown anti-angiogenic effects. It decreased, in a dose dependent manner $(1-10 \mu \mathrm{g} / \mathrm{ml})$ the expression of VEGF-A. The inhibitory effects were the result of inhibition of VEGFR-2 phosphorylation (108).

Taken together, experimental evidence suggests that volatile anesthetics might promote tumor progression by directly modifying intracellular signals involved in key aspects of cancer cell behavior such as proliferation, migration and invasion. Additionally, volatile anesthetics might promote immunosuppression. In contrast, propofol has shown antiinflammatory properties and potentiation of the immune response. Data for ketamine and dexmedetomidine is inconsistent with some studies showing promotion of tumor progression while other showing opposite findings. On the other hand, lidocaine has shown promising results.

\section{CLINICAL EVIDENCE}

Retrospective studies (Table 1) indicate that cancer survival and recurrence could be affected by the anesthetic technique. The most recent systematic review and meta-analysis by Chang et al. included 19 retrospective observational studies of patients undergoing surgery for various types of cancer surgery. (130) Pool analysis of OS included 17 studies with 23,489 patients $(110,113-119,121-124,126,128,131,132)$. The study showed that propofol-based TIVA in cancer surgery was associated with better OS compared to volatile agents $(\mathrm{HR}=0.79,95 \% \mathrm{CI}$, $0.66-0.94, \mathrm{p}=0.08)$. Interestingly the results of the subgroup analysis by volatile anesthetics showed that this benefit was statistically significant only when TIVA was compared to desflurane $(\mathrm{HR}=0.54,95 \% \mathrm{CI}, 0.36-0.80, \mathrm{p}=0.03)$, but not compared to sevoflurane $(\mathrm{HR}=0.92,95 \% \mathrm{CI}, 0.74-1.14, \mathrm{p}=.436)$ or other volatile agents $(\mathrm{HR}=0.83,96 \% \mathrm{CI}, 0.64-1.07, \mathrm{p}=0.156)$. In terms of RFS, the study pooled the results of 10 studies with 8,980 patients $(110,113,114,116,117,123,124,126,127,132)$. 
TABLE 1 | Retrospective trials comparing the effect of TIVA versus volatile anesthesia on long-term cancer outcomes.

\begin{tabular}{llll}
\hline Type of Cancer & Author & Overall Survival & Recurrence- Free Survival \\
\hline Gastrointestinal & $(109)$ & No difference & No difference \\
Hepatocellular & $(110)$ & No studied & Increased with TIVA \\
Glioblastoma & $(111)$ & No difference & No difference \\
Breast & $(112)$ & No difference & No difference \\
Glioma & $(113)$ & No difference & No difference \\
Breast & $(114)$ & No difference & No difference \\
Gastric & $(115)$ & No difference & No difference \\
Cholangiocarcinoma & $(116)$ & Increased with TIVA & No difference \\
Hepatocellular & $(117)$ & Increased with TIVA & Increased with TIVA \\
Breast & $(118)$ & No difference & No difference \\
Breast, Liver, Lung and Gastrointestinal & $(119)$ & No difference & No difference \\
Appendiceal & $(120)$ & No difference & No difference \\
Gastric & $(121)$ & Increased with TIVA & No studied \\
Colon & $(122)$ & Increased with TIVA & No studied \\
Lung & $(123)$ & No difference & No difference \\
Breast & $(124)$ & No difference & No difference \\
Glioblastoma & $(125)$ & No difference & No difference \\
Esophageal & $(126)$ & No difference & No difference \\
Breast & $(127)$ & No difference & No difference \\
Breast, Sarcoma Gastrointestinal and Urologic & $(128)$ & Increased with TIVA & No studied \\
Ovarian & $(129)$ & No studied & Increased with volatile anesthetic \\
\hline
\end{tabular}

The analysis indicated no benefits in survival when using TIVA compared to volatile agents $(\mathrm{HR}=0.92,95 \% \mathrm{CI}, 0.74$ $1.14, \mathrm{p}=0.439)$.

Interestingly the benefits in OS in Chang's work were seen in patients with gastrointestinal malignancies, which is the same type of cancers included in another study done by Yap et al (133). Importantly, this group of investigators found that the use of propofol-based TIVA not only improved OS ( $\mathrm{HR}=0.76,95 \% \mathrm{CI}$, $0.63-0.92, \mathrm{p}<0.01)$ but also improved RFS ( $\mathrm{HR}=0.78,95 \% \mathrm{CI}$, $0.65-0.94, \mathrm{p}<0.01)$. There are some important study limitations that need to be highlighted when analyzing the available metaanalyses. For example, Wigmore et al. study acknowledged the difference in the baseline characteristics between groups, with more ASA III/IV patients, more complex surgeries and larger metastatic burden in the volatile anesthetics group. Nevertheless after propensity matching to correct potential confunders, the study groups were similar (128). Lai's study presented the same limitation for hepatocellular carcinoma surgery. In that study, the desflurane group had significantly more patients with worse preoperative functional capacity, higher scores of liver disease and tumor grade staging compared to the propofol-based group. Patients in the desflurane group were also more likely to have larger tumors and receive blood transfusions which are all independent factor associated with decreased survival (117).

It is important to point out that the systematic review conducted by Chang et al. included studies published until March 2020 and unfortunately did not include the largest retrospective study done by Makito et al. (which was published later in the same year) (109). In that retrospective study the author investigated the effect of TIVA and volatile agents on long-term oncological outcomes among 196,303 patients with gastrointestinal malignancies and found that $\mathrm{OS}(\mathrm{HR}=1.02,95 \%$ $\mathrm{CI}, 0.98-1.07, \mathrm{p}=0.28)$ and $\mathrm{RFS}(\mathrm{HR}=0.99,95 \% \mathrm{CI}, 0.96-1.03, \mathrm{P}=$ 0.59) were similar between propofol-based TIVA and volatile anesthetic groups. Similar to Makito's work, other multiple retrospective studies showed no difference between TIVA and volatile in terms of OS and RFS in patients with breast cancer $(114,118,124,131)$. The lack of benefit from propofol-based TIVA has also been described for lung $(123,134)$ and brain cancer surgeries $(111,113,125)$. Subsequent substudies from RCTs in lung and breast cancer indicated the same results (134136). However, it is important to point out that these RCTs did not have OS and RFS as primary outcome.

Since retrospective studies have significant limitations, RCTs are necessary to determine whether the use of propofol-based anesthesia modifies cancer outcomes in patients undergoing surgery for solid tumors (Table 2). The VAPOR-C trial (NCT04074460) has a 2x2 factorial design and will investigate the impact of TIVA vs. inhalational agents and lidocaine vs. placebo on DFS after lung and colorectal cancer surgery with curative intent (stage 1-3) (138). The cancer and anesthesia study (NCT01975064) is also investigating the effect of propofol-based TIVA versus volatile anesthesia in breast and colon cancer patients. Preliminary data for 1-year survival is already available and unsurprisingly no benefit was observed in the propofol-based TIVA group (137). The results from long-term survival (5 years) are expected to be available for 2022-2023. The GA-CARES trial (NCT03034096) will randomize 2,000 patients to assess all-cause mortality and RFS in patient undergoing lung,

TABLE 2 | Randomized control trials comparing the effect of TIVA versus volatile anesthesia on long-term cancer outcomes.

\begin{tabular}{lcll}
\hline Type of Cancer & Author & Overall Survival & Recurrence- Free Survival \\
\hline Breast & $(137)$ & ${ }^{*}$ No difference & No published yet \\
Breast & $(135)$ & No difference & No difference \\
Breast & $(136)$ & No difference & No difference \\
Lung & $(134)$ & No difference & No difference \\
\hline
\end{tabular}

*Preliminary data from 1 year OS. 
TABLE 3 | Retrospective trials assessing the effect of regional anesthesia on long-term cancer outcomes.

\begin{tabular}{|c|c|c|c|c|}
\hline Type of Cancer & Author & Intervention & Overall Survival & Cancer Recurrence \\
\hline Colon & $(145)$ & Epidural & No benefit from RA & No benefit from RA \\
\hline Colon & $(146)$ & Epidural & No benefit from RA & Benefit from RA \\
\hline Colon & $(147)$ & Epidural & Benefit from RA & No reported \\
\hline Colon & (148) & Epidural & Benefit from RA & No reported \\
\hline Colon & (149) & Epidural & Benefit from RA & No benefit from RA \\
\hline Colon & $(150)$ & Epidural & No benefit & No benefit \\
\hline Colorectal & (151) & Epidural & Benefit from RA & No reported \\
\hline Colon & (152) & Epidural & No reported & No benefit \\
\hline Breast & (153) & Loco-regional anesthesia & No benefit from RA & No benefit from RA \\
\hline Breast & (154) & Paravertebral block & No benefit from RA & No benefit from RA \\
\hline Breast & (155) & Paravertebral block & No benefit from RA & No benefit from RA \\
\hline Breast & (156) & Paravertebral block & No reported & No benefit from RA \\
\hline Breast & (157) & $\begin{array}{l}\text { Epidural } \\
\text { Paravertebral block }\end{array}$ & No reported & No benefit from RA \\
\hline Breast & (158) & Paravertebral block & No reported & Benefit from RA \\
\hline Prostate & (159) & Spinal & No reported & No benefit from RA \\
\hline Prostate & (160) & Epidural & No benefit from RA & No benefit from RA \\
\hline Prostate & $(161)$ & Spinal & No reported & No benefit from RA \\
\hline Prostate & $(162)$ & Spinal & No benefit from RA & No benefit from RA \\
\hline Prostate & (163) & Spinal & No reported & No benefit from RA \\
\hline Prostate & (164) & Epidural & No benefit from RA & No benefit from RA \\
\hline Prostate & $(165)$ & Epidural & No reported & No benefit RA \\
\hline Prostate & $(166)$ & Epidural & No benefit from RA & Benefit from RA \\
\hline Prostate & $(167)$ & Epidural & No reported & Benefit from RA \\
\hline Ovarian & (129) & Epidural & No reported & Benefit from RA \\
\hline Ovarian & (168) & Epidural & No benefit from RA & No benefit from RA \\
\hline Ovarian & (169) & Epidural & No benefit from RA & No benefit from RA \\
\hline Ovarian & $(170)$ & Epidural & Benefit from RA & No reported \\
\hline Ovarian & $(171)$ & Epidural & No reported & Benefit from RA \\
\hline
\end{tabular}

TABLE 4 | Randomized control trials assessing the effect of regional anesthesia on long-term cancer outcomes.

\begin{tabular}{|c|c|c|c|c|}
\hline Type of Cancer & Author & Intervention & Overall Survival & Cancer Recurrence \\
\hline Lung & $(172)$ & Epidural & No benefit from RA & No benefit from RA \\
\hline Thoracic and Abdominal & $(173)$ & Epidural & No benefit from RA & No benefit from RA \\
\hline Breast & $(135)$ & Paravertebral block & No reported & No benefit from RA \\
\hline Breast & (174) & Paravertebral block & No benefit from RA & No benefit from RA \\
\hline Breast & $(175)$ & Paravertebral block & No reported & No benefit from RA \\
\hline Colon & $(176)$ & Epidural & No benefit from RA & No benefit from RA \\
\hline Colon & (177) & Epidural & No benefit from RA & No benefit from RA \\
\hline Colon & (178) & Epidural & Benefit with RA & No reported \\
\hline Prostate & $(179)$ & Epidural & No reported & No benefit from RA \\
\hline
\end{tabular}

bladder, esophagus, pancreas, liver, gastric and biliary duct cancer surgery with propofol-based anesthesia or volatile anesthetics.

The effect of intravenous lidocaine on cancer outcomes was recently investigated in pancreatic surgery. A retrospective study of more than 2,239 patients assessed the effect of intraoperative lidocaine (bolus injection of $1.5 \mathrm{mg} / \mathrm{kg}$ followed by continues infusion $2 \mathrm{mg} / \mathrm{kg} /$ hour) and suggested that intravenous lidocaine was associated with prolonged OS ( $\mathrm{HR}=0.616,95 \% \mathrm{CI}, 0.290$ 0.783, $\mathrm{p}=0.013$ ), but not DFS ( $\mathrm{HR}=0.913,95 \% \mathrm{CI}, 0.821-1.612$, $\mathrm{p}=0.011)(139)$.

In conclusion, the current evidence is weak to indicate that propofol-based general anesthesia provides any oncological benefit to patients with cancer requiring surgery.

\section{REGIONAL ANESTHESIA COMPARED TO GENERAL ANESTHESIA FOR CANCER SURGERY}

Regional anesthesia (RA) techniques including peripheral nerve blocks and neuraxial anesthesia were associated with a reduction in cancer recurrence in preclinical and observational studies. it was originally theorized that RA could improve oncological outcomes after cancer surgery since RA decreases the neuroendocrine response to surgical trauma, opioid consumption and the use of volatile anesthetics (140-142). Additionally, RA preserves the function of the immune system and has a direct inhibitory effect on cancer cells $(143,144)$. 


\section{CLINICAL EVIDENCE}

Thus far, the evidence regarding the potential benefits of RA in long-term outcomes originates from preclinical, retrospective, post hoc analysis of RCT and few RCTs (Tables 3, 4). The most recent RCT enrolled 400 patients to investigate the effect of combined epidural-general or general anesthesia alone in patients undergoing video-assisted thoracoscopic lung cancer resection. The primary outcome was RFS. Secondary outcomes were OS and cancer-specific survival. The median follow-up was after 32 months. Results indicated that epidural-anesthesia for major lung surgery did not improved RFS (HR $=0.90$, CI 95\% $0.60-1.35, \mathrm{p}=0.068)$, cancer-specific survival ( $\mathrm{HR}=1.08$, CI 95\% $0.61-1.91, \mathrm{p}=0.802)$ or OS (HR=1.12, CI 95\% 0.6401.96, $\mathrm{p}=0.697)$ compared to general anesthesia alone (172),

The effect of combined epidural-general was also investigated in a large RCT including patients $(\mathrm{n}=1,712)$ undergoing major non-cardiac thoracic or abdominal surgery. The median followup time was after 5 years. Again, mortality ( $\mathrm{HR}=1.07$, CI $95 \%$ 0.92- 1.24, $\mathrm{p}=0.408$ ), cancer-specific survival $(\mathrm{HR}=1.09$, CI $95 \%$ $0.93-1.28, \mathrm{p}=0.290)$ and RFS (HR=0.97, CI 95\% 0.84-1.12, $\mathrm{p}=0.692$ ) was similar between combined epidural-general anesthesia and general anesthesia group. (173) In the setting of breast cancer surgery, two RCTs also failed to demonstrate any benefits from paravertebral blocks in terms of cancer outcomes in patients undergoing breast cancer surgery $(135,174)$. Other RCTs looking at the effect of RA on colon and prostate cancer surgery also failed to demonstrate any benefits in cancer outcomes $(177,179)$.

There are multiple RCTs in progress to determine the effects of RA compared to general anesthesia on cancer progression. The study NCT03597087 will assess RFS and PFS in patients undergoing transurethral resection of bladder tumors under spinal anesthesia. NCT03245346 will investigate the effect of epidurals on OS and RFS in patients undergoing pancreatic cancer surgery. This trial will also assess the inflammatory neuro-endocrine response by measuring norepinephrine, epinephrine, cortisol and IL-6, IL-8 levels and by

\section{REFERENCES}

1. Ahmad FB, Anderson RN. The Leading Causes of Death in the US for 2020. JAMA (2021) 325(18):1829-30. doi: 10.1001/jama.2021.5469

2. Siegel RL, Miller KD, Jemal A. Cancer Statistics 2020. CA Cancer J Clin (2020) 70(1):7-30. doi: 10.3322/caac.21590

3. Siegel RL, Miller KD, Fuchs HE, Jemal A. Cancer Statistics 2021. CA Cancer J Clin (2021) 71(1):7-33. doi: 10.3322/caac.21654

4. Kim R. Effects of Surgery and Anesthetic Choice on Immunosuppression and Cancer Recurrence. J Transl Med (2018) 16(1):8. doi: 10.1186/s12967-018-1389-7

5. Dillekas H, Rogers MS, Straume O. Are $90 \%$ of Deaths From Cancer Caused by Metastases? Cancer Med (2019) 8(12):5574-6. doi: 10.1002/cam4.2474

6. Popper H. Primary Tumor and Metastasis-Sectioning the Different Steps of the Metastatic Cascade. Transl Lung Cancer Res (2020) 9(5):2277-300. doi: $10.21037 /$ tlcr-20-175

7. Brabletz T, Kalluri R, Nieto MA, Weinberg RA. EMT in Cancer. Nat Rev Cancer (2018) 18(2):128-34. doi: 10.1038/nrc.2017.118

8. Hansen E, Wolff N, Knuechel R, Ruschoff J, Hofstaedter F, Taeger K. Tumor Cells in Blood Shed From the Surgical Field. Arch Surg (1995) 130(4):38793. doi: 10.1001/archsurg.1995.01430040049007 measuring the neutrophil-lymphocyte ratio. Lastly, NCT02786329 will investigate the effect of epidural anesthesia in patients undergoing lung cancer resection.

In conclusion, a growing body of evidence from RCTs consistently demonstrates that cancer-specific mortality and cancer recurrence are not improved by the use of regional anesthesia during oncologic surgery.

\section{CONCLUSION}

Cancer surgery remains the standard of care for patients with solid tumors. Despite curative intent, $90 \%$ of cancer mortality is secondary to cancer metastasis. Preclinical data suggest that the perioperative stress response to surgical trauma creates a window of opportunity for accelerated tumor growth and metastasis. This effect seems to be secondary to changes in signaling pathways in bothTME and immune response. Total intravenous anesthesia and regional anesthesia have been proposed as strategies to counteract the inflammatory response and the associated immunosuppression associated with cancer surgery. Unfortunately, the majority of the data looking at the relationship of these techniques and cancer outcomes originates from retrospective studies. Whether volatile anesthetics have a deleterious effect of cancer recurrence and survival remains a controversial issue. RCTs are in progress and will explore a causal relationship between volatile anesthetic and cancer outcomes. As far for regional anesthesia, RTCs have consistently shown lack of benefit of this technique in regards to cancer survival and recurrence.

\section{AUTHOR CONTRIBUTIONS}

MR and JC: discussed ideas and prepared the manuscript. MR: prepared figures and tables. JC: improved manuscript and edited. All authors contributed to the article and approved the submitted version.

9. Yam MF, Loh YC, Tan CS, Khadijah Adam S, Abdul Manan N, Basir R. General Pathways of Pain Sensation and the Major Neurotransmitters Involved in Pain Regulation. Int J Mol Sci (2018) 19(8):1-23. doi: 10.3390/ ijms 19082164

10. Grivennikov SI, Karin M. Inflammatory Cytokines in Cancer: Tumour Necrosis Factor and Interleukin 6 Take the Stage. Ann Rheum Dis (2011) 70 Suppl 1:i104-8. doi: 10.1136/ard.2010.140145

11. Romagnani S. T-Cell Subsets (Th1 Versus Th2). Ann Allergy Asthma Immunol (2000) 85(1):9-18; quiz 18, 21. doi: 10.1016/S1081-1206(10) 62426-X

12. Huang C, Huang R, Jiang T, Huang K, Cao J, Qiu Z. Laparoscopic and Open Resection for Colorectal Cancer: An Evaluation of Cellular Immunity. BMC Gastroenterol (2010) 10:127. doi: 10.1186/1471-230X-10-127

13. Inflammatory Response After Laparoscopic Versus Open Resection of Colorectal Liver Metastases Data From the Oslo-CoMet Trial: Erratum. Med (Baltimore) (2016) 95(10):e367e. doi: 10.1097/01.md.0000481801.40636.7e

14. Hogan BV, Peter MB, Shenoy HG, Horgan K, Hughes TA. Surgery Induced Immunosuppression. Surgeon (2011) 9(1):38-43. doi: 10.1016/j.surge.2010.07.011

15. Ni Choileain N, Redmond HP. Cell Response to Surgery. Arch Surg (2006) 141(11):1132-40. doi: 10.1001/archsurg.141.11.1132 
16. Agard M, Asakrah S, Morici LA. PGE(2) Suppression of Innate Immunity During Mucosal Bacterial Infection. Front Cell Infect Microbiol (2013) 3:45. doi: $10.3389 /$ fcimb.2013.00045

17. Martinet L, Jean C, Dietrich G, Fournie JJ, Poupot R. PGE2 Inhibits Natural Killer and Gamma Delta T Cell Cytotoxicity Triggered by NKR and TCR Through a cAMP-Mediated PKA Type I-Dependent Signaling. Biochem Pharmacol (2010) 80(6):838-45. doi: 10.1016/j.bcp.2010.05.002

18. Karnezis T, Shayan R, Caesar C, Roufail S, Harris NC, Ardipradja K, et al. VEGF-D Promotes Tumor Metastasis by Regulating Prostaglandins Produced by the Collecting Lymphatic Endothelium. Cancer Cell (2012) 21(2):181-95. doi: 10.1016/j.ccr.2011.12.026

19. Treffkorn L, Scheibe R, Maruyama T, Dieter P. PGE2 Exerts its Effect on the LPS-Induced Release of TNF-Alpha, ET-1, IL-1alpha, IL-6 and IL-10 via the EP2 and EP4 Receptor in Rat Liver Macrophages. Prostaglandins Other Lipid Mediat (2004) 74(1-4):113-23. doi: 10.1016/j.prostaglandins.2004.07.005

20. Ellyard JI, Simson L, Parish CR. Th2-Mediated Anti-Tumour Immunity: Friend or Foe? Tissue Antigens (2007) 70(1):1-11. doi: 10.1111/j.13990039.2007.00869.x

21. Finnerty CC, Mabvuure NT, Ali A, Kozar RA, Herndon DN. The Surgically Induced Stress Response. JPEN J Parenter Enteral Nutr (2013) 37(5 Suppl):21S-9S. doi: 10.1177/0148607113496117

22. Quatrini L, Ugolini S. New Insights Into the Cell- and Tissue-Specificity of Glucocorticoid Actions. Cell Mol Immunol (2021) 18(2):269-78. doi: 10.1038/s41423-020-00526-2

23. Bernabe DG, Tamae AC, Biasoli ER, Oliveira SH. Stress Hormones Increase Cell Proliferation and Regulates Interleukin-6 Secretion in Human Oral Squamous Cell Carcinoma Cells. Brain Behav Immun (2011) 25(3):574-83. doi: 10.1016/j.bbi.2010.12.012

24. Zhang H, Kong Q, Wang J, Jiang Y, Hua H. Complex Roles of cAMP-PKACREB Signaling in Cancer. Exp Hematol Oncol (2020) 9(1):32. doi: 10.1186/ s40164-020-00191-1

25. Braadland PR, Ramberg H, Grytli HH, Tasken KA. Beta-Adrenergic Receptor Signaling in Prostate Cancer. Front Oncol (2014) 375:375. doi: $10.3389 /$ fonc. 2014.00375

26. Choy C, Raytis JL, Smith DD, Duenas M, Neman J, Jandial R, et al. Inhibition of Beta2-Adrenergic Receptor Reduces Triple-Negative Breast Cancer Brain Metastases: The Potential Benefit of Perioperative BetaBlockade. Oncol Rep (2016) 35(6):3135-42. doi: 10.3892/or.2016.4710

27. Huang Q, Tan Q, Mao K, Yang G, Ma G, Luo P, et al. The Role of Adrenergic Receptors in Lung Cancer. Am J Cancer Res (2018) 8(11):2227-37.

28. Liu J, Qu L, Wan C, Xiao M, Ni W, Jiang F, et al. A Novel Beta2-AR/YB-1/BetaCatenin Axis Mediates Chronic Stress-Associated Metastasis in Hepatocellular Carcinoma. Oncogenesis (2020) 9(9):84. doi: 10.1038/s41389-020-00268-w

29. Liu X, Wu WK, Yu L, Sung JJ, Srivastava G, Zhang ST, et al. Epinephrine Stimulates Esophageal Squamous-Cell Carcinoma Cell Proliferation via Beta-Adrenoceptor-Dependent Transactivation of Extracellular SignalRegulated Kinase/Cyclooxygenase-2 Pathway. J Cell Biochem (2008) 105 (1):53-60. doi: 10.1002/jcb.21802

30. Gould CM, Courtneidge SA. Regulation of Invadopodia by the Tumor Microenvironment. Cell Adh Migr (2014) 8(3):226-35. doi: 10.4161/cam.28346

31. Creed SJ, Le CP, Hassan M, Pon CK, Albold S, Chan KT, et al. Beta2Adrenoceptor Signaling Regulates Invadopodia Formation to Enhance Tumor Cell Invasion. Breast Cancer Res (2015) 17(1):145. doi: 10.1186/ s13058-015-0655-3

32. Karayiannakis AJ, Syrigos KN, Zbar A, Baibas N, Polychronidis A, Simopoulos C, et al. Clinical Significance of Preoperative Serum Vascular Endothelial Growth Factor Levels in Patients With Colorectal Cancer and the Effect of Tumor Surgery. Surgery (2002) 131(5):548-55. doi: 10.1067/msy.2002.123011

33. Vidal O, Metges JP, Elizalde I, Valentini M, Volant A, Molina R, et al. High Preoperative Serum Vascular Endothelial Growth Factor Levels Predict Poor Clinical Outcome After Curative Resection of Gastric Cancer. Br J Surg (2009) 96(12):1443-51. doi: 10.1002/bjs.6780

34. Sia D, Alsinet C, Newell P, Villanueva A. VEGF Signaling in Cancer Treatment. Curr Pharm Des (2014) 20(17):2834-42. doi: 10.2174/ 13816128113199990590

35. Song M, Finley SD. Mechanistic Insight Into Activation of MAPK Signaling by Pro-Angiogenic Factors. BMC Syst Biol (2018) 12(1):145. doi: 10.1186/ s12918-018-0668-5
36. Duque JL, Loughlin KR, Adam RM, Kantoff PW, Zurakowski D, Freeman MR. Plasma Levels of Vascular Endothelial Growth Factor Are Increased in Patients With Metastatic Prostate Cancer. Urology (1999) 54(3):523-7. doi: 10.1016/s0090-4295(99)00167-3

37. Georgiou GK, Igglezou M, Sainis I, Vareli K, Batsis H, Briasoulis E, et al. Impact of Breast Cancer Surgery on Angiogenesis Circulating Biomarkers: A Prospective Longitudinal Study. World J Surg Oncol (2013) 11:213. doi: 10.1186/1477-7819-11-213

38. Niu Q, Tang ZY, Ma ZC, Qin LX, Zhang LH. Serum Vascular Endothelial Growth Factor Is a Potential Biomarker of Metastatic Recurrence After Curative Resection of Hepatocellular Carcinoma. World J Gastroenterol (2000) 6(4):565-8. doi: 10.3748/wjg.v6.i4.565

39. Salven P, Perhoniemi V, Tykka H, Maenpaa H, Joensuu H. Serum VEGF Levels in Women With a Benign Breast Tumor or Breast Cancer. Breast Cancer Res Treat (1999) 53(2):161-6. doi: 10.1023/a:1006178517505

40. Jaillon S, Ponzetta A, Di Mitri D, Santoni A, Bonecchi R, Mantovani A. Neutrophil Diversity and Plasticity in Tumour Progression and Therapy. Nat Rev Cancer (2020) 20(9):485-503. doi: 10.1038/s41568-020-0281-y

41. Jensen HK, Donskov F, Marcussen N, Nordsmark M, Lundbeck F, von der Maase H. Presence of Intratumoral Neutrophils Is an Independent Prognostic Factor in Localized Renal Cell Carcinoma. J Clin Oncol (2009) 27(28):4709-17. doi: 10.1200/JCO.2008.18.9498

42. Schmidt H, Bastholt L, Geertsen P, Christensen IJ, Larsen S, Gehl J, et al. Elevated Neutrophil and Monocyte Counts in Peripheral Blood Are Associated With Poor Survival in Patients With Metastatic Melanoma: A Prognostic Model. Br J Cancer (2005) 93(3):273-8. doi: 10.1038/sj.bjc.6602702

43. Shu Q, Hu ZL, Huang C, Yu XW, Fan H, Yang JW, et al. Orexin-A Promotes Cell Migration in Cultured Rat Astrocytes via Ca2+-Dependent PKCalpha and ERK1/2 Signals. PloS One (2014) 9(4):e95259. doi: 10.1371/ journal.pone.0095259

44. Yang L, Liu Q, Zhang X, Liu X, Zhou B, Chen J, et al. DNA of Neutrophil Extracellular Traps Promotes Cancer Metastasis via CCDC25. Nature (2020) 583(7814):133-8. doi: 10.1038/s41586-020-2394-6

45. Cools-Lartigue J, Spicer J, McDonald B, Gowing S, Chow S, Giannias B, et al. Neutrophil Extracellular Traps Sequester Circulating Tumor Cells and Promote Metastasis. J Clin Invest (2013), 3446-58. doi: 10.1172/JCI67484

46. Toffoli EC, Sheikhi A, Hoppner YD, de Kok P, Yazdanpanah-Samani M, Spanholtz J, et al. Natural Killer Cells and Anti-Cancer Therapies: Reciprocal Effects on Immune Function and Therapeutic Response. Cancers (Basel) (2021) 13(4). doi: 10.3390/cancers13040711

47. Moretta L, Bottino C, Pende D, Vitale M, Mingari MC, Moretta A. Human Natural Killer Cells: Molecular Mechanisms Controlling NK Cell Activation and Tumor Cell Lysis. Immunol Lett (2005) 100(1):7-13. doi: 10.1016/ j.imlet.2005.07.004

48. Iannone F, Porzia A, Peruzzi G, Birarelli P, Milana B, Sacco L, et al. Effect of Surgery on Pancreatic Tumor-Dependent Lymphocyte Asset: Modulation of Natural Killer Cell Frequency and Cytotoxic Function. Pancreas (2015) 44 (3):386-93. doi: 10.1097/MPA.0000000000000288

49. Angka L, Martel AB, Kilgour M, Jeong A, Sadiq M, de Souza CT, et al. Natural Killer Cell IFNgamma Secretion Is Profoundly Suppressed Following Colorectal Cancer Surgery. Ann Surg Oncol (2018) 25(12):374754. doi: 10.1245/s10434-018-6691-3

50. Shi L, Guo H, Zheng Z, Liu J, Jiang Y, Su Y. Laparoscopic Surgery Versus Open Surgery for Colorectal Cancer: Impacts on Natural Killer Cells. Cancer Control (2020) 27(1):1073274820906811. doi: 10.1177/1073274820906811

51. Garcea G, Ladwa N, Neal CP, Metcalfe MS, Dennison AR, Berry DP. Preoperative Neutrophil-to-Lymphocyte Ratio (NLR) Is Associated With Reduced Disease-Free Survival Following Curative Resection of Pancreatic Adenocarcinoma. World J Surg (2011) 35(4):868-72. doi: 10.1007/s00268011-0984-z

52. Hung HY, Chen JS, Yeh CY, Changchien CR, Tang R, Hsieh PS, et al. Effect of Preoperative Neutrophil-Lymphocyte Ratio on the Surgical Outcomes of Stage II Colon Cancer Patients Who do Not Receive Adjuvant Chemotherapy. Int $J$ Colorectal Dis (2011) 26(8):1059-65. doi: 10.1007/s00384-011-1192-x

53. Tomita M, Shimizu T, Ayabe T, Yonei A, Onitsuka T. Preoperative Neutrophil to Lymphocyte Ratio as a Prognostic Predictor After Curative Resection for non-Small Cell Lung Cancer. Anticancer Res (2011) 31 (9):2995-8. doi: 10.2478/jomb-2019-0031 
54. Cupp MA, Cariolou M, Tzoulaki I, Aune D, Evangelou E, Berlanga-Taylor AJ. Neutrophil to Lymphocyte Ratio and Cancer Prognosis: An Umbrella Review of Systematic Reviews and Meta-Analyses of Observational Studies. BMC Med (2020) 18(1):360. doi: 10.1186/s12916-020-01817-1

55. Forget P, Machiels JP, Coulie PG, Berliere M, Poncelet AJ, Tombal B, et al. Neutrophil:lymphocyte Ratio and Intraoperative Use of Ketorolac or Diclofenac Are Prognostic Factors in Different Cohorts of Patients Undergoing Breast, Lung, and Kidney Cancer Surgery. Ann Surg Oncol (2013) 20 Suppl 3:S650-60. doi: 10.1245/s10434-013-3136-x

56. Choi JE, Villarreal J, Lasala J, Gottumukkala V, Mehran RJ, Rice D, et al. Perioperative Neutrophil:Lymphocyte Ratio and Postoperative NSAID Use as Predictors of Survival After Lung Cancer Surgery: A Retrospective Study. Cancer Med (2015) 4(6):825-33. doi: 10.1002/cam4.428

57. Zhao H, Liao X, Kang Y. Tregs: Where We Are and What Comes Next? Front Immunol (2017) 8:1578. doi: 10.3389/fimmu.2017.01578

58. Ghiringhelli FO, Ménard CD, Terme M, Flament C, Taieb J, Chaput N, et al. CD4+CD25+ Regulatory T Cells Inhibit Natural Killer Cell Functions in a Transforming Growth Factor- $\beta$-Dependent Manner. J Exp Med (2005) 202 (8):1075-85. doi: $10.1084 /$ jem.20051511

59. Liyanage UK, Moore TT, Joo HG, Tanaka Y, Herrmann V, Doherty G, et al. Prevalence of Regulatory T Cells Is Increased in Peripheral Blood and Tumor Microenvironment of Patients With Pancreas or Breast Adenocarcinoma. J Immunol (2002) 169(5):2756-61. doi: 10.4049/jimmunol.169.5.2756

60. Scholz AS, Handke J, Gillmann HJ, Zhang Q, Dehne S, Janssen H, et al. Frontline Science: Low Regulatory T Cells Predict Perioperative Major Adverse Cardiovascular and Cerebrovascular Events After Noncardiac Surgery. J Leukoc Biol (2019) 107(5):717-30. doi: 10.1002/jlb.5hi1018-392rr

61. Benzonana LL, Perry NJ, Watts HR, Yang B, Perry IA, Coombes C, et al. Isoflurane, a Commonly Used Volatile Anesthetic, Enhances Renal Cancer Growth and Malignant Potential via the Hypoxia-Inducible Factor Cellular Signaling Pathway In Vitro. Anesthesiology (2013) 119(3):593-605. doi: 10.1097/ALN.0b013e31829e47fd

62. Zhu M, Li M, Zhou Y, Dangelmajer S, Kahlert UD, Xie R, et al. Isoflurane Enhances the Malignant Potential of Glioblastoma Stem Cells by Promoting Their Viability, Mobility In Vitro and Migratory Capacity In Vivo. Br J Anaesth (2016) 116(6):870-7. doi: 10.1093/bja/aew124

63. Zhang W, Shao X. Isoflurane Promotes Non-Small Cell Lung Cancer Malignancy by Activating the Akt-Mammalian Target of Rapamycin (mTOR) Signaling Pathway. Med Sci Monit (2016) 22:4644-50. doi: $10.12659 / \mathrm{msm} .898434$

64. Ren J, Wang X, Wei G, Meng Y. Exposure to Desflurane Anesthesia Confers Colorectal Cancer Cells Metastatic Capacity Through Deregulation of miR34a/LOXL3. Eur J Cancer Prev (2021) 30(2):143-53. doi: 10.1097/ CEJ.0000000000000608

65. Deng X, Vipani M, Liang G, Gouda D, Wang B, Wei H. Sevoflurane Modulates Breast Cancer Cell Survival via Modulation of Intracellular Calcium Homeostasis. BMC Anesthesiol (2020) 20(1):253. doi: 10.1186/ s12871-020-01139-y

66. Tazawa K, Koutsogiannaki S, Chamberlain M, Yuki K. The Effect of Different Anesthetics on Tumor Cytotoxicity by Natural Killer Cells. Toxicol Lett (2017) 266:23-31. doi: 10.1016/j.toxlet.2016.12.007

67. Markovic SN, Knight PR, Murasko DM. Inhibition of Interferon Stimulation of Natural Killer Cell Activity in Mice Anesthetized With Halothane or Isoflurane. Anesthesiology (1993) 78(4):700-6. doi: 10.1097/00000542199304000-00013

68. Mitsuhata H, Shimizu R, Yokoyama MM. Suppressive Effects of Volatile Anesthetics on Cytokine Release in Human Peripheral Blood Mononuclear Cells. Int J Immunopharmacol (1995) 17(6):529-34. doi: 10.1016/0192-0561 (95)00026-X

69. Ciechanowicz S, Zhao H, Chen Q, Cui J, Mi E, Mi E, et al. Differential Effects of Sevoflurane on the Metastatic Potential and Chemosensitivity of nonSmall-Cell Lung Adenocarcinoma and Renal Cell Carcinoma In Vitro. Br J Anaesth (2018) 120(2):368-75. doi: 10.1016/j.bja.2017.11.066

70. Liang H, Gu M, Yang C, Wang H, Wen X, Zhou Q. Sevoflurane Inhibits Invasion and Migration of Lung Cancer Cells by Inactivating the P38 MAPK Signaling Pathway. J Anesth (2012) 26(3):381-92. doi: 10.1007/s00540-011-1317-y

71. Liang H, Yang CX, Zhang B, Wang HB, Liu HZ, Lai XH, et al. Sevoflurane Suppresses Hypoxia-Induced Growth and Metastasis of Lung Cancer Cells via Inhibiting Hypoxia-Inducible Factor-1alpha. J Anesth (2015) 29(6):82130. doi: 10.1007/s00540-015-2035-7

72. Fan L, Wu Y, Wang J, He J, Han X. Sevoflurane Inhibits the Migration and Invasion of Colorectal Cancer Cells Through Regulating ERK/MMP-9 Pathway by Up-Regulating miR-203. Eur J Pharmacol (2019) 850:43-52. doi: 10.1016/j.ejphar.2019.01.025

73. Kvolik S, Dobrosevic B, Marczi S, Prlic L, Glavas-Obrovac L. Different Apoptosis Ratios and Gene Expressions in Two Human Cell Lines After Sevoflurane Anaesthesia. Acta Anaesthesiol Scand (2009) 53(9):1192-9. doi: 10.1111/j.1399-6576.2009.02036.x

74. Gao K, Su Z, Liu H, Liu Y. Anti-Proliferation and Anti-Metastatic Effects of Sevoflurane on Human Osteosarcoma U2OS and Saos-2 Cells. Exp Mol Pathol (2019) 108:121-30. doi: 10.1016/j.yexmp.2019.04.005

75. Li Y, Dong W, Yang H, Xiao G. Propofol Suppresses Proliferation and Metastasis of Colorectal Cancer Cells by Regulating miR-124-3p.1/AKT3. Biotechnol Lett (2020) 42(3):493-504. doi: 10.1007/s10529-019-02787-y

76. Miao Y, Zhang Y, Wan H, Chen L, Wang F. GABA-Receptor Agonist, Propofol Inhibits Invasion of Colon Carcinoma Cells. BioMed Pharmacother (2010) 64(9):583-8. doi: 10.1016/j.biopha.2010.03.006

77. Xing SG, Zhang KJ, Qu JH, Ren YD, Luan Q. Propofol Induces Apoptosis of non-Small Cell Lung Cancer Cells via ERK1/2-Dependent Upregulation of PUMA. Eur Rev Med Pharmacol Sci (2018) 22(13):4341-9. doi: 10.26355/ eurrev_201807_15431

78. Yang N, Liang Y, Yang P, Ji F. Propofol Suppresses LPS-Induced Nuclear Accumulation of HIF-1alpha and Tumor Aggressiveness in Non-Small Cell Lung Cancer. Oncol Rep (2017) 37(5):2611-9. doi: 10.3892/or.2017.5514

79. Wu KC, Yang ST, Hsia TC, Yang JS, Chiou SM, Lu CC, et al. Suppression of Cell Invasion and Migration by Propofol Are Involved in Down-Regulating Matrix Metalloproteinase-2 and P38 MAPK Signaling in A549 Human Lung Adenocarcinoma Epithelial Cells. Anticancer Res (2012) 32(11):4833-42.

80. Li Q, Zhang L, Han Y, Jiang Z, Wang Q. Propofol Reduces MMPs Expression by Inhibiting NF-kappaB Activity in Human MDA-MB-231 Cells. BioMed Pharmacother (2012) 66(1):52-6. doi: 10.1016/ j.biopha.2011.10.006

81. Wang D, Yang T, Liu J, Liu Y, Xing N, He J, et al. Propofol Inhibits the Migration and Invasion of Glioma Cells by Blocking the PI3K/AKT Pathway Through miR-206/ROCK1 Axis. Onco Targets Ther (2020) 13:361-70. doi: 10.2147/OTT.S232601

82. Yang C, Xia Z, Li T, Chen Y, Zhao M, Sun Y, et al. Antioxidant Effect of Propofol in Gliomas and Its Association With Divalent Metal Transporter 1. Front Oncol (2020) 10:590931. doi: 10.3389/fonc.2020.590931

83. Liu D, Sun X, Du Y, Kong M. Propofol Promotes Activity and TumorKilling Ability of Natural Killer Cells in Peripheral Blood of Patients With Colon Cancer. Med Sci Monit (2018) 24:6119-28. doi: 10.12659/ MSM. 911218

84. Zhou M, Dai J, Zhou Y, Wu J, Xu T, Zhou D, et al. Propofol Improves the Function of Natural Killer Cells From the Peripheral Blood of Patients With Esophageal Squamous Cell Carcinoma. Exp Ther Med (2018) 16(1):83-92. doi: 10.3892/etm.2018.6140

85. Helmy SA, Al-Attiyah RJ. The Immunomodulatory Effects of Prolonged Intravenous Infusion of Propofol Versus Midazolam in Critically Ill Surgical Patients. Anaesthesia (2001) 56(1):4-8. doi: 10.1046/j.1365-2044. 2001.01713.x

86. Inada T, Hirota K, Shingu K. Intravenous Anesthetic Propofol Suppresses Prostaglandin E2 and Cysteinyl Leukotriene Production and Reduces Edema Formation in Arachidonic Acid-Induced Ear Inflammation. J Immunotoxicol (2015) 12(3):261-5. doi: 10.3109/1547691X.2014.938874

87. Chen MS, Lin WC, Yeh HT, Hu CL, Sheu SM. Propofol Specifically Reduces PMA-Induced Neutrophil Extracellular Trap Formation Through Inhibition of P-ERK and HOCl. Life Sci (2019) 221:178-86. doi: 10.1016/ j.lfs. 2019.02 .030

88. Meier A, Chien J, Hobohm L, Patras KA, Nizet V, Corriden R. Inhibition of Human Neutrophil Extracellular Trap (NET) Production by Propofol and Lipid Emulsion. Front Pharmacol (2019) 10:323. doi: 10.3389/ fphar.2019.00323

89. Li T, Yang J, Yang B, Zhao G, Lin H, Liu Q, et al. Ketamine Inhibits Ovarian Cancer Cell Growth by Regulating the IncRNA-PVT1/EZH2/p57 Axis. Front Genet (2020) 11:597467. doi: 10.3389/fgene.2020.597467 
90. Duan W, Hu J, Liu Y. Ketamine Inhibits Colorectal Cancer Cells Malignant Potential via Blockage of NMDA Receptor. Exp Mol Pathol (2019) 107:1718. doi: 10.1016/j.yexmp.2019.02.004

91. Zhou X, Zhang P, Luo W, Zhang L, Hu R, Sun Y, et al. Ketamine Induces Apoptosis in Lung Adenocarcinoma Cells by Regulating the Expression of CD69. Cancer Med (2018) 7(3):788-95. doi: 10.1002/cam4.1288

92. Lee ST, Wu TT, Yu PY, Chen RM. Apoptotic Insults to Human HepG2 Cells Induced by $\mathrm{S}-(+)$-Ketamine Occurs Through Activation of a BaxMitochondria-Caspase Protease Pathway. Br J Anaesth (2009) 102(1):80-9. doi: $10.1093 /$ bja/aen322

93. Malsy M, Gebhardt K, Gruber M, Wiese C, Graf B, Bundscherer A. Effects of Ketamine, s-Ketamine, and MK 801 on Proliferation, Apoptosis, and Necrosis in Pancreatic Cancer Cells. BMC Anesthesiol (2015) 15:111. doi: 10.1186/s12871-015-0076-y

94. Zhang P, He H, Bai Y, Liu W, Huang L. Dexmedetomidine Suppresses the Progression of Esophageal Cancer via miR-143-3p/Epidermal Growth Factor Receptor Pathway Substrate 8 Axis. Anticancer Drugs (2020) 31 (7):693-701. doi: 10.1097/CAD.0000000000000934

95. Bruzzone A, Pinero CP, Castillo LF, Sarappa MG, Rojas P, Lanari C, et al. Alpha2-Adrenoceptor Action on Cell Proliferation and Mammary Tumour Growth in Mice. Br J Pharmacol (2008) 155(4):494-504. doi: 10.1038/ bip. 2008.278

96. Szpunar MJ, Burke KA, Dawes RP, Brown EB, Madden KS. The Antidepressant Desipramine and Alpha2-Adrenergic Receptor Activation Promote Breast Tumor Progression in Association With Altered Collagen Structure. Cancer Prev Res (Phila) (2013) 6(12):1262-72. doi: 10.1158/19406207.CAPR-13-0079

97. Chen P, Luo X, Dai G, Jiang Y, Luo Y, Peng S, et al. Dexmedetomidine Promotes the Progression of Hepatocellular Carcinoma Through Hepatic Stellate Cell Activation. Exp Mol Med (2020) 52(7):1062-74. doi: 10.1038/ s12276-020-0461-6

98. Wang C, Datoo T, Zhao H, Wu L, Date A, Jiang C, et al. Midazolam and Dexmedetomidine Affect Neuroglioma and Lung Carcinoma Cell Biology In Vitro and In Vivo. Anesthesiology (2018) 129(5):1000-14. doi: 10.1097/ ALN.0000000000002401

99. Lavon H, Matzner P, Benbenishty A, Sorski L, Rossene E, Haldar R, et al. Dexmedetomidine Promotes Metastasis in Rodent Models of Breast, Lung, and Colon Cancers. Br J Anaesth (2018) 120(1):188-96. doi: 10.1016/j.bja.2017.11.004

100. Sun H, Sun Y. Lidocaine Inhibits Proliferation and Metastasis of Lung Cancer Cell via Regulation of miR-539/EGFR Axis. Artif Cells Nanomed Biotechnol (2019) 47(1):2866-74. doi: 10.1080/21691401.2019.1636807

101. Xing W, Chen DT, Pan JH, Chen YH, Yan Y, Li Q, et al. Lidocaine Induces Apoptosis and Suppresses Tumor Growth in Human Hepatocellular Carcinoma Cells In Vitro and in a Xenograft Model In Vivo. Anesthesiology (2017) 126(5):868-81. doi: 10.1097/ALN.0000000000001528

102. Zhu J, Han S. Lidocaine Inhibits Cervical Cancer Cell Proliferation and Induces Cell Apoptosis by Modulating the lncRNA-MEG3/miR-421/BTG1 Pathway. Am J Transl Res (2019) 11(9):5404-16.

103. Chiu KM, Lu CW, Lee MY, Wang MJ, Lin TY, Wang SJ. Neuroprotective and Anti-Inflammatory Effects of Lidocaine in Kainic Acid-Injected Rats. Neuroreport (2016) 27(7):501-7. doi: 10.1097/WNR.0000000000000570

104. Lan W, Harmon DC, Wang JH, Shorten GD, Redmond PH. Activated Endothelial Interleukin-1beta, -6, and -8 Concentrations and Intercellular Adhesion Molecule-1 Expression Are Attenuated by Lidocaine. Anesth Analg (2005) 100(2):409-12. doi: 10.1213/01.ANE.0000142113.39092.87

105. Yardeni IZ, Beilin B, Mayburd E, Levinson Y, Bessler H. The Effect of Perioperative Intravenous Lidocaine on Postoperative Pain and Immune Function. Anesth Analg (2009) 109(5):1464-9. doi: 10.1213/ANE. 0b013e3181bab1bd

106. Cata JP, Ramirez MF, Velasquez JF, Di AI, Popat KU, Gottumukkala V, et al. Lidocaine Stimulates the Function of Natural Killer Cells in Different Experimental Settings. Anticancer Res (2017) 37(9):4727-32. doi: 10.21873/ anticanres.11879

107. Galos EV, Tat TF, Popa R, Efrimescu CI, Finnerty D, Buggy DJ, et al. Neutrophil Extracellular Trapping and Angiogenesis Biomarkers After Intravenous or Inhalation Anaesthesia With or Without Intravenous Lidocaine for Breast Cancer Surgery: A Prospective, Randomised Trial. Br $J$ Anaesth (2020) 125(5):712-21. doi: 10.1016/j.bja.2020.05.003
108. Suzuki S, Mori A, Fukui A, Ema Y, Nishiwaki K. Lidocaine Inhibits Vascular Endothelial Growth Factor-A-Induced Angiogenesis. J Anesth (2020) 34 (6):857-64. doi: 10.1007/s00540-020-02830-7

109. Makito K, Matsui H, Fushimi K, Yasunaga H. Volatile Versus Total Intravenous Anesthesia for Cancer Prognosis in Patients Having Digestive Cancer Surgery. Anesthesiology (2020) 133(4):764-73. doi: 10.1097/ ALN.0000000000003440

110. Koo BW, Lim DJ, Oh AY, Na HS. Retrospective Comparison Between the Effects of Propofol and Inhalation Anesthetics on Postoperative Recurrence of Early- and Intermediate-Stage Hepatocellular Carcinoma. Med Princ Pract (2020) 29(5):422-8. doi: 10.1159/000506637

111. Grau SJ, Lohr M, Taurisano V, Trautner H, Timmer M, Schwab SG, et al. The Choice of Anaesthesia for Glioblastoma Surgery Does Not Impact the Time to Recurrence. Sci Rep (2020) 10(1):5556. doi: 10.1038/s41598-02062087-8

112. Enlund M, Berglund A, Ahlstrand R, Wallden J, Lundberg J, Warnberg F, et al. Survival After Primary Breast Cancer Surgery Following Propofol or Sevoflurane General Anesthesia-A Retrospective, Multicenter, Database Analysis of 6305 Swedish Patients. Acta Anaesthesiol Scand (2020) 64 (8):1048-54. doi: 10.1111/aas.13644

113. Dong J, Zeng M, Ji N, Hao S, Zhou Y, Gao Z, et al. Impact of Anesthesia on Long-Term Outcomes in Patients With Supratentorial High-Grade Glioma Undergoing Tumor Resection: A Retrospective Cohort Study. J Neurosurg Anesthesiol (2020) 32(3):227-33. doi: 10.1097/ANA.0000000000000588

114. Yoo S, Lee HB, Han W, Noh DY, Park SK, Kim WH, et al. Total Intravenous Anesthesia Versus Inhalation Anesthesia for Breast Cancer Surgery: A Retrospective Cohort Study. Anesthesiology (2019) 130(1):31-40. doi: 10.1097/ALN.0000000000002491

115. Oh TK, Kim HH, Jeon YT. Retrospective Analysis of 1-Year Mortality After Gastric Cancer Surgery: Total Intravenous Anesthesia Versus Volatile Anesthesia. Acta Anaesthesiol Scand (2019) 63(9):1169-77. doi: 10.1111/aas.13414

116. Lai HC, Lee MS, Lin KT, Chan SM, Chen JY, Lin YT, et al. Propofol-Based Total Intravenous Anesthesia Is Associated With Better Survival Than Desflurane Anesthesia in Intrahepatic Cholangiocarcinoma Surgery. Med (Baltimore) (2019) 98(51):e18472. doi: 10.1097/MD.0000000000018472

117. Lai HC, Lee MS, Lin C, Lin KT, Huang YH, Wong CS, et al. Propofol-Based Total Intravenous Anaesthesia Is Associated With Better Survival Than Desflurane Anaesthesia in Hepatectomy for Hepatocellular Carcinoma: A Retrospective Cohort Study. Br J Anaesth (2019) 123(2):151-60. doi: 10.1016/j.bja.2019.04.057

118. Huang YH, Lee MS, Lou YS, Lai HC, Yu JC, Lu CH, et al. Propofol-Based Total Intravenous Anesthesia did Not Improve Survival Compared to Desflurane Anesthesia in Breast Cancer Surgery. PloS One (2019) 14(11): e0224728. doi: 10.1371/journal.pone.0224728

119. Hong B, Lee S, Kim Y, Lee M, Youn AM, Rhim H, et al. Anesthetics and Long-Term Survival After Cancer Surgery-Total Intravenous Versus Volatile Anesthesia: A Retrospective Study. BMC Anesthesiol (2019) 19(1):233. doi: 10.1186/s12871-019-0914-4

120. Cata JP, Nguyen LT, Ifeanyi-Pillette IC, Van Meter A, Dangler LA, Feng L, et al. An Assessment of the Survival Impact of Multimodal Anesthesia/Analgesia Technique in Adults Undergoing Cytoreductive Surgery With Hyperthermic Intraperitoneal Chemotherapy: A Propensity Score Matched Analysis. Int J Hyperthermia (2019) 36(1):369-75. doi: 10.1080/02656736.2019.1574985

121. Zheng X, Wang Y, Dong L, Zhao S, Wang L, Chen H, et al. Effects of PropofolBased Total Intravenous Anesthesia on Gastric Cancer: A Retrospective Study. Onco Targets Ther (2018) 11:1141-8. doi: 10.2147/OTT.S156792

122. Wu ZF, Lee MS, Wong CS, Lu CH, Huang YS, Lin KT, et al. Propofol-Based Total Intravenous Anesthesia Is Associated With Better Survival Than Desflurane Anesthesia in Colon Cancer Surgery. Anesthesiology (2018) 129 (5):932-41. doi: 10.1097/ALN.0000000000002357

123. Oh TK, Kim K, Jheon S, Lee J, Do SH, Hwang JW, et al. Long-Term Oncologic Outcomes for Patients Undergoing Volatile Versus Intravenous Anesthesia for Non-Small Cell Lung Cancer Surgery: A Retrospective Propensity Matching Analysis. Cancer Control (2018) 25 (1):1073274818775360. doi: 10.1177/1073274818775360

124. Kim MH, Kim DW, Kim JH, Lee KY, Park S, Yoo YC. Does the Type of Anesthesia Really Affect the Recurrence-Free Survival After Breast Cancer Surgery? Oncotarget (2017) 8(52):90477-87. doi: 10.18632/oncotarget.21014 
125. Cata JP, Hagan KB, Bhavsar SD, Arunkumar R, Grasu R, Dang A, et al. The Use of Isoflurane and Desflurane as Inhalational Agents for Glioblastoma Surgery. A Survival Analysis. J Clin Neurosci (2017) 35:82-7. doi: 10.1016/ j.jocn.2016.10.006

126. Jun IJ, Jo JY, Kim JI, Chin JH, Kim WJ, Kim HR, et al. Impact of Anesthetic Agents on Overall and Recurrence-Free Survival in Patients Undergoing Esophageal Cancer Surgery: A Retrospective Observational Study. Sci Rep (2017) 7(1):14020. doi: 10.1038/s41598-017-14147-9

127. Lee JH, Kang SH, Kim Y, Kim HA, Kim BS. Effects of Propofol-Based Total Intravenous Anesthesia on Recurrence and Overall Survival in Patients After Modified Radical Mastectomy: A Retrospective Study. Korean J Anesthesiol (2016) 69(2):126-32. doi: 10.4097/kjae.2016.69.2.126

128. Wigmore TJ, Mohammed K, Jhanji S. Long-Term Survival for Patients Undergoing Volatile Versus IV Anesthesia for Cancer Surgery: A Retrospective Analysis. Anesthesiology (2016) 124(1):69-79. doi: 10.1097/ ALN.0000000000000936

129. Elias KM, Kang S, Liu X, Horowitz NS, Berkowitz RS, Frendl G. Anesthetic Selection and Disease-Free Survival Following Optimal Primary Cytoreductive Surgery for Stage III Epithelial Ovarian Cancer. Ann Surg Oncol (2015) 22(4):1341-8. doi: 10.1245/s10434-014-4112-9

130. Chang CY, Wu MY, Chien YJ, Su IM, Wang SC, Kao MC. Anesthesia and Long-Term Oncological Outcomes: A Systematic Review and Meta-Analysis. Anesth Analg (2021) 132(3):623-34. doi: 10.1213/ANE.0000000000005237

131. Enlund M, Berglund A, Andreasson K, Cicek C, Enlund A, Bergkvist L. The Choice of Anaesthetic-Sevoflurane or Propofol-and Outcome From Cancer Surgery: A Retrospective Analysis. Ups J Med Sci (2014) 119(3):251-61. doi: 10.3109/03009734.2014.922649

132. Sung CH, Tsuang FY, Shih CC, Chang JL, Liao MH, Yang YW, et al. Scalp Block Is Associated With Improved Recurrence Profiles in Patients Undergoing Primary Glioma Resection Surgery. J Neurosurg Anesthesiol (2021) 33(3):239-46. doi: 10.1097/ANA.0000000000000664

133. Yap A, Lopez-Olivo MA, Dubowitz J, Hiller J, Riedel BGlobal Onco-Anesthesia Research Collaboration, G. Anesthetic Technique and Cancer Outcomes: A Meta-Analysis of Total Intravenous Versus Volatile Anesthesia. Can J Anaesth (2019) 66(5):546-61. doi: 10.1007/s12630-019-01330-x

134. Xu Q, Shi NJ, Zhang H, Zhu YM. Effects of Combined General-Epidural Anesthesia and Total Intravenous Anesthesia on Cellular Immunity and Prognosis in Patients With Nonsmall Cell Lung Cancer: A Comparative Study. Mol Med Rep (2017) 16(4):4445-54. doi: 10.3892/mmr.2017.7144

135. Sessler DI, Pei L, Huang Y, Fleischmann E, Marhofer P, Kurz A, et al. Recurrence of Breast Cancer After Regional or General Anaesthesia: A Randomised Controlled Trial. Lancet (2019) 394(10211):1807-15. doi: 10.1016/S0140-6736(19)32313-X

136. Yan T, Zhang GH, Wang BN, Sun L, Zheng H. Effects of Propofol/ Remifentanil-Based Total Intravenous Anesthesia Versus SevofluraneBased Inhalational Anesthesia on the Release of VEGF-C and TGF-Beta and Prognosis After Breast Cancer Surgery: A Prospective, Randomized and Controlled Study. BMC Anesthesiol (2018) 18(1):131. doi: 10.1186/s12871018-0588-3

137. Enlund M. Is It Definitely Clear That Long-Term Survival After Breast Cancer Surgery Is Not Affected by Anaesthetics? Cancers (Basel) (2021) 13 (14). doi: 10.3390/cancers 13143390

138. Dubowitz JA, Cata JP, De Silva AP, Braat S, Shan D, Yee K, et al. Volatile Anaesthesia and Peri-Operative Outcomes Related to Cancer: A Feasibility and Pilot Study for a Large Randomised Control Trial. Anaesthesia (2021) 76 (9):1198-206. doi: 10.1111/anae.15354

139. Zhang H, Yang L, Zhu X, Zhu M, Sun Z, Cata JP, et al. Association Between Intraoperative Intravenous Lidocaine Infusion and Survival in Patients Undergoing Pancreatectomy for Pancreatic Cancer: A Retrospective Study. Br J Anaesth (2020) 125(2):141-8. doi: 10.1016/j.bja.2020.03.034

140. Calvo-Soto P, Martinez-Contreras A, Hernandez BT, And FP, Vasquez C. Spinal-General Anaesthesia Decreases Neuroendocrine Stress Response in Laparoscopic Cholecystectomy. J Int Med Res (2012) 40(2):657-65. doi: $10.1177 / 147323001204000228$

141. Ingelmo PM, Ferri F, Fumagalli R. Interactions Between General and Regional Anesthesia. Minerva Anestesiol (2006) 72(6):437-45.

142. Kumar K, Kirksey MA, Duong S, Wu CL. A Review of Opioid-Sparing Modalities in Perioperative Pain Management: Methods to Decrease Opioid
Use Postoperatively. Anesth Analg (2017) 125(5):1749-60. doi: 10.1213/ ANE.0000000000002497

143. Perez-Gonzalez O, Cuellar-Guzman LF, Soliz J, Cata JP. Impact of Regional Anesthesia on Recurrence, Metastasis, and Immune Response in Breast Cancer Surgery: A Systematic Review of the Literature. Reg Anesth Pain Med (2017) 42(6):751-6. doi: 10.1097/AAP.0000000000000662

144. Zhang Y, Peng X, Zheng Q. Ropivacaine Inhibits the Migration of Esophageal Cancer Cells via Sodium-Channel-Independent But Prenylation-Dependent Inhibition of Racl/JNK/Paxillin/FAK. Biochem Biophys Res Commun (2018) 501(4):1074-9. doi: 10.1016/j.bbrc.2018.05.110

145. Tai YH, Chang WK, Wu HL, Chan MY, Chen HH, Chang KY. The Effect of Epidural Analgesia on Cancer Progression in Patients With Stage IV Colorectal Cancer After Primary Tumor Resection: A Retrospective Cohort Study. PloS One (2018) 13(7):e0200893. doi: 10.1371/journal. pone. 0200893

146. Zimmitti G, Soliz J, Aloia TA, Gottumukkala V, Cata JP, Tzeng CW, et al. Positive Impact of Epidural Analgesia on Oncologic Outcomes in Patients Undergoing Resection of Colorectal Liver Metastases. Ann Surg Oncol (2016) 23(3):1003-11. doi: 10.1245/s10434-015-4933-1

147. Vogelaar FJ, Abegg R, van der Linden JC, Cornelisse HG, van Dorsten FR, Lemmens VE, et al. Epidural Analgesia Associated With Better Survival in Colon Cancer. Int J Colorectal Dis (2015) 30(8):1103-7. doi: 10.1007/s00384015-2224-8

148. Holler JP, Ahlbrandt J, Burkhardt E, Gruss M, Rohrig R, Knapheide J, et al. Peridural Analgesia may Affect Long-Term Survival in Patients With Colorectal Cancer After Surgery (PACO-RAS-Study): An Analysis of a Cancer Registry. Ann Surg (2013) 258(6):989-93. doi: 10.1097/SLA. 0b013e3182915f61

149. Cummings KC3rd, Xu F, Cummings LC, Cooper GS. A Comparison of Epidural Analgesia and Traditional Pain Management Effects on Survival and Cancer Recurrence After Colectomy: A Population-Based Study. Anesthesiology (2012) 116(4):797-806. doi: 10.1097/ALN.0b013e31824674f6

150. Day A, Smith R, Jourdan I, Fawcett W, Scott M, Rockall T. Retrospective Analysis of the Effect of Postoperative Analgesia on Survival in Patients After Laparoscopic Resection of Colorectal Cancer. Br J Anaesth (2012) 109 (2):185-90. doi: 10.1093/bja/aes106

151. Gupta A, Bjornsson A, Fredriksson M, Hallbook O, Eintrei C. Reduction in Mortality After Epidural Anaesthesia and Analgesia in Patients Undergoing Rectal But Not Colonic Cancer Surgery: A Retrospective Analysis of Data From 655 Patients in Central Sweden. Br J Anaesth (2011) 107(2):164-70. doi: 10.1093/bja/aer100

152. Gottschalk A, Ford JG, Regelin CC, You J, Mascha EJ, Sessler DI, et al. Association Between Epidural Analgesia and Cancer Recurrence After Colorectal Cancer Surgery. Anesthesiology (2010) 113(1):27-34. doi: 10.1097/ALN.0b013e3181de6d0d

153. Tsigonis AM, Al-Hamadani M, Linebarger JH, Vang CA, Krause FJ, Johnson JM, et al. Are Cure Rates for Breast Cancer Improved by Local and Regional Anesthesia? Reg Anesth Pain Med (2016) 41(3):339-47. doi: 10.1097/ AAP.0000000000000379

154. Kairaluoma P, Mattson J, Heikkila P, Pere P, Leidenius M. Perioperative Paravertebral Regional Anaesthesia and Breast Cancer Recurrence. Anticancer Res (2016) 36(1):415-8. doi: 10.2165/00128413-200615610-00023

155. Cata JP, Chavez-MacGregor M, Valero V, Black W, Black DM, Goravanchi F, et al. The Impact of Paravertebral Block Analgesia on Breast Cancer Survival After Surgery. Reg Anesth Pain Med (2016) 41(6):696-703. doi: 10.1097/AAP.0000000000000479

156. Starnes-Ott K, Goravanchi F, Meininger JC. Anesthetic Choices and Breast Cancer Recurrence: A Retrospective Pilot Study of Patient, Disease, and Treatment Factors. Crit Care Nurs Q (2015) 38(2):200-10. doi: 10.1097/ CNQ.0000000000000062

157. Koonce SL, McLaughlin SA, Eck DL, Porter S, Bagaria S, Clendenen SR, et al. Breast Cancer Recurrence in Patients Receiving Epidural and Paravertebral Anesthesia: A Retrospective, Case-Control Study. Middle East J Anaesthesiol (2014) 22(6):567-71.

158. Exadaktylos AK, Buggy DJ, Moriarty DC, Mascha E, Sessler DI. Can Anesthetic Technique for Primary Breast Cancer Surgery Affect Recurrence or Metastasis? Anesthesiology (2006) 105(4):660-4. doi: 10.1097/00000542-200610000-00008 
159. Tseng KS, Kulkarni S, Humphreys EB, Carter HB, Mostwin JL, Partin AW, et al. Spinal Anesthesia Does Not Impact Prostate Cancer Recurrence in a Cohort of Men Undergoing Radical Prostatectomy: An Observational Study. Reg Anesth Pain Med (2014) 39(4):284-8. doi: 10.1097/AAP.0000000000000108

160. Sprung J, Scavonetto F, Yeoh TY, Kramer JM, Karnes RJ, Eisenach JH, et al. Outcomes After Radical Prostatectomy for Cancer: A Comparison Between General Anesthesia and Epidural Anesthesia With Fentanyl Analgesia: A Matched Cohort Study. Anesth Analg (2014) 119(4):859-66. doi: 10.1213/ ANE.0000000000000320

161. Scavonetto F, Yeoh TY, Umbreit EC, Weingarten TN, Gettman MT, Frank I, et al. Association Between Neuraxial Analgesia, Cancer Progression, and Mortality After Radical Prostatectomy: A Large, Retrospective Matched Cohort Study. Br J Anaesth (2014) 113 Suppl 1:i95-102. doi: 10.1093/bja/aet467

162. Roiss M, Schiffmann J, Tennstedt P, Kessler T, Blanc I, Goetz A, et al. Oncological Long-Term Outcome of 4772 Patients With Prostate Cancer Undergoing Radical Prostatectomy: Does the Anaesthetic Technique Matter? Eur J Surg Oncol (2014) 40(12):1686-92. doi: 10.1016/j.ejso.2014.02.223

163. Ehdaie B, Sjoberg DD, Dalecki PH, Scardino PT, Eastham JA, Amar D. Association of Anesthesia Technique for Radical Prostatectomy With Biochemical Recurrence: A Retrospective Cohort Study. Can J Anaesth (2014) 61(12):1068-74. doi: 10.1007/s12630-014-0221-y

164. Wuethrich PY, Thalmann GN, Studer UE, Burkhard FC. Epidural Analgesia During Open Radical Prostatectomy Does Not Improve Long-Term CancerRelated Outcome: A Retrospective Study in Patients With Advanced Prostate Cancer. PloS One (2013) 8(8):e72873. doi: 10.1371/journal.pone.0072873

165. Forget P, Tombal B, Scholtes JL, Nzimbala J, Meulders C, Legrand C, et al. Do Intraoperative Analgesics Influence Oncological Outcomes After Radical Prostatectomy for Prostate Cancer? Eur J Anaesthesiol (2011) 28(12):830-5. doi: 10.1097/EJA.0b013e32834b7d9a

166. Wuethrich PY, Hsu Schmitz SF, Kessler TM, Thalmann GN, Studer UE, Stueber F, et al. Potential Influence of the Anesthetic Technique Used During Open Radical Prostatectomy on Prostate Cancer-Related Outcome: A Retrospective Study. Anesthesiology (2010) 113(3):570-6. doi: 10.1097/ ALN.0b013e3181e4f6ec

167. Biki B, Mascha E, Moriarty DC, Fitzpatrick JM, Sessler DI, Buggy DJ. Anesthetic Technique for Radical Prostatectomy Surgery Affects Cancer Recurrence: A Retrospective Analysis. Anesthesiology (2008) 109(2):180-7. doi: 10.1097/ALN.0b013e31817f5b73

168. Lacassie HJ, Cartagena J, Branes J, Assel M, Echevarria GC. The Relationship Between Neuraxial Anesthesia and Advanced Ovarian Cancer-Related Outcomes in the Chilean Population. Anesth Analg (2013) 117(3):653-60. doi: 10.1213/ANE.0b013e3182a07046

169. Capmas P, Billard V, Gouy S, Lhomme C, Pautier P, Morice P, et al. Impact of Epidural Analgesia on Survival in Patients Undergoing Complete Cytoreductive Surgery for Ovarian Cancer. Anticancer Res (2012) 32(4):1537-42.

170. Lin L, Liu C, Tan H, Ouyang H, Zhang Y, Zeng W. Anaesthetic Technique may Affect Prognosis for Ovarian Serous Adenocarcinoma: A Retrospective Analysis. Br J Anaesth (2011) 106(6):814-22. doi: 10.1093/bja/aer055

171. de Oliveira GSJr., Ahmad S, Schink JC, Singh DK, Fitzgerald PC, McCarthy RJ. Intraoperative Neuraxial Anesthesia But Not Postoperative Neuraxial Analgesia Is Associated With Increased Relapse-Free Survival in Ovarian Cancer Patients After Primary Cytoreductive Surgery. Reg Anesth Pain Med (2011) 36(3):271-7. doi: 10.1097/AAP.0b013e318217aada
172. Xu ZZ, Li HJ, Li MH, Huang SM, Li X, Liu QH, et al. Epidural Anesthesia-Analgesia and Recurrence-Free Survival After Lung Cancer Surgery: A Randomized Trial. Anesthesiol (2021). doi: 10.1097/ ALN.0000000000003873

173. Du YT, Li YW, Zhao BJ, Guo XY, Feng Y, Zuo MZ, et al. Long-Term Survival After Combined Epidural-General Anesthesia or General Anesthesia Alone: Follow-Up of a Randomized Trial. Anesthesiology (2021) 135(2):233-45. doi: 10.1097/ALN.0000000000003835

174. Karmakar MK, Samy W, Lee A, Li JW, Chan WC, Chen PP, et al. Survival Analysis of Patients With Breast Cancer Undergoing a Modified Radical Mastectomy With or Without a Thoracic Paravertebral Block: A 5-Year Follow-Up of a Randomized Controlled Trial. Anticancer Res (2017) 37 (10):5813-20. doi: 10.21873/anticanres.12024

175. Finn DM, Ilfeld BM, Unkart JT, Madison SJ, Suresh PJ, Sandhu NPS, et al. Post-Mastectomy Cancer Recurrence With and Without a Continuous Paravertebral Block in the Immediate Postoperative Period: A Prospective Multi-Year Follow-Up Pilot Study of a Randomized, Triple-Masked, Placebo-Controlled Investigation. J Anesth (2017) 31(3):374-9. doi: 10.1007/s00540-017-2345-z

176. Binczak M, Tournay E, Billard V, Rey A, Jayr C. Major Abdominal Surgery for Cancer: Does Epidural Analgesia Have a Long-Term Effect on Recurrence-Free and Overall Survival? Ann Fr Anesth Reanim (2013) 32 (5):e81-88. doi: 10.1016/j.annfar.2013.02.027

177. Myles PS, Peyton P, Silbert B, Hunt J, Rigg JR, Sessler DI, et al. Perioperative Epidural Analgesia for Major Abdominal Surgery for Cancer and Recurrence-Free Survival: Randomised Trial. BMJ (2011) 342:d1491. doi: $10.1136 / b m j . d 1491$

178. Christopherson R, James KE, Tableman M, Marshall P, Johnson FE. LongTerm Survival After Colon Cancer Surgery: A Variation Associated With Choice of Anesthesia. Anesth Analg (2008) 107(1):325-32. doi: 10.1213/ ane.0b013e3181770f55

179. Tsui BC, Rashiq S, Schopflocher D, Murtha A, Broemling S, Pillay J, et al. Epidural Anesthesia and Cancer Recurrence Rates After Radical Prostatectomy. Can J Anaesth (2010) 57(2):107-12. doi: 10.1007/s12630009-9214-7

Conflict of Interest: The authors declare that the research was conducted in the absence of any commercial or financial relationships that could be construed as a potential conflict of interest.

Publisher's Note: All claims expressed in this article are solely those of the authors and do not necessarily represent those of their affiliated organizations, or those of the publisher, the editors and the reviewers. Any product that may be evaluated in this article, or claim that may be made by its manufacturer, is not guaranteed or endorsed by the publisher.

Copyright $\odot 2021$ Ramirez and Cata. This is an open-access article distributed under the terms of the Creative Commons Attribution License (CC BY). The use, distribution or reproduction in other forums is permitted, provided the original author(s) and the copyright owner(s) are credited and that the original publication in this journal is cited, in accordance with accepted academic practice. No use, distribution or reproduction is permitted which does not comply with these terms. 